\title{
De "teatro" a "cinema": o plenário do Tribunal do Júri do Rio de Janeiro e as representações sobre as formas de se fazer justiça criminal.
}

\section{The theater became a cinema: how a Court in Rio de Janeiro may show what Brazilian people think about criminal justice.}

Izabel Saenger Nuñez ${ }^{1}$

\section{RESUMO}

Por meio da descrição do espaço físico de uma das Varas do Tribunal do Júri do Rio de Janeiro, o artigo pretende explicitar como a organização espacial local está relacionada com as concepções dos agentes sobre o fazer judicial. Assim, desde a descrição do espaço, demonstra como as representações sobre justiça e participação popular foram materializadas em um afastamento do público, representado como sociedade, isolamento dos jurados, considerados a participação popular na justiça e distanciamento do conflito, fazendo sobressair no ambiente concreto a inquisitorialidade de nossa justiça e a centralidade do papel do juiz sobre o dos jurados.

\section{PALAVRAS-CHAVE:}

Espaço físico; tribunais; concepções sobre o fazer judicial.

\begin{abstract}
This paper aims to show how the court space reverberates and reflects what people who work on it think about justice. Regarding describing and analyzing one of the Courts where Trial by Jury happens in Rio de Janeiro, I intend to show how it demonstrates certain ideias of social participation, turned into jurors isolation, judge centralization and showing the inquisitoriality that is enforced here in Brazilian Justice.
\end{abstract}

\section{KEY-WORDS:}

Space, courts, ideas of judicial work.

\footnotetext{
${ }^{1}$ Doutora em Antropologia pelo PPGA/UFF (2018). Doutoranda em Direito pela UERJ. Mestre em Ciências Jurídicas e Sociais pelo PPGSD/UFF (2012). Bacharel em Ciências Jurídicas e Sociais pela PUCRS (2007). Atualmente é pesquisadora de pós doutorado (PNPD/CAPES) vinculada ao Núcleo Fluminense de Estudos e Pesquisa (NUFEP/PPGA/UFF). É vice coordenadora do Núcleo de Estudos e Pesquisas sobre Sujeitos, Sociedade e Estado (NEPSSE/UFF), pesquisadora do Instituto Nacional de Estudos Comparados em Administração Institucional de Conflitos (INCT-InEAC) e da Associação de Pesquisa Data Privacy Brasil. Contato: izabelsn@gmail.com. Lattes: http://lattes.cnpq.br/3792527214805610.
} 


\section{INTRODUÇÃO}

O "plenário" do Tribunal do Júri é o lugar por excelência onde acontecem os rituais de julgamento dos "crimes dolosos contra a vida" no Brasil. Tais rituais são, presumivelmente, públicos, e deveriam por isso aproximar a sociedade do fazer judicial. Este artigo pretende trazer reflexões a partir da análise do espaço físico do atual Plenário do Júri da Cidade do Rio de Janeiro, demonstrando como as transformações produzidas no seu desenho espacial refletem a própria concepção do que é fazer justiça, por parte dos operadores do direito. E, não por outro motivo, os espaços podem ser pensados, inclusive, como uma expressão concreta das representações sobre a justiça e outros valores existentes no caso brasileiro.

Há poucos trabalhos que buscam compreender o espaço específico das cortes como espaço social, como "espaço transformado pela ação humana", embora essa seja uma abordagem mais comum no campo da geografia (VESETINI, 1986, p. 7) e da antropologia (HOLSTON, 1989) urbanas. Nesse sentido o texto de Mulcahy (2007) explicita as mudanças espaciais produzidas em um tribunal inglês, mais especificamente, nas Criminal Assizes, que foram extintas, mas cujos espaço seguiram sendo usados e seus usos adaptados, demonstrando as mudanças procedimentais pelas quais o processo e os espaços judiciais passaram mutuamente. Este artigo, a seu turno, pretende evidenciar como a organização do espaço físico do Tribunal do Júri no Rio de Janeiro está intimamente ligado às representações que os agentes do sistema de justiça têm, sobre o fazer judicial (EILBAUM, 2012) e como ela explícita valores e concepçõe sobre a justiça, tornando-as concretas, materializadas e traduzidas no recinto.

O Júri da Capital fluminense foi especialmente remodelado no ano de 2012. Dentre as modificações, uma das mais marcantes se deu com o isolamento que separa a plateia do plenário, mediante a instalação de um vidro blindado entre eles, e a colocação dos jurados de costas para público, afastados do réu e de seus defensores, impossibilitando que os primeiros avaliem as expressões dos envolvidos no caso. Ainda, posicionou esses últimos em altura inferior ao juiz e ao Ministério Público. Por fim, alocou a mesa das testemunhas e réus de frente para o magistrado e MP e de costas para os jurados. O juiz, então, tornou-se o personagem central do Júri. Toda essa modificação implicou uma importante transformação em sua dinâmica, particularmente descartando uma atuação decisiva dos jurados, e impedindo o seu contato com a prova que deveria ser produzida, para eles, em plenário. 
Tais alterações no espaço refletem-se no afastamento da sociedade e na ausência - ou em uma reduzida - participação popular, por meio do um maior isolamento da plateia, dos jurados e dos agentes do judiciário. São essas mudanças, suas reações no fazer judicial e, como essas mudanças falam sobre as concepções de justiça, que pretendo trabalhar nesse artigo. $\mathrm{O}$ material empírico para sua escrita decorre de um ano e meio de trabalho de campo de observação das práticas judiciais no contexto de uma das varas do Tribunal do Júri da Comarca do Rio de Janeiro ${ }^{2}$, que realizei para a escrita de minha tese de doutorado (NUÑEZ, 2021).

\section{O PLENÁRIO DO JÚRI}

As varas do Tribunal do Júri do Rio de Janeiro funcionam no Foro Central, onde funcionam da Comarca e estão localizadas atualmente nos andares oito e nove do referido prédio, situado na Avenida Erasmo Braga, próximo à Praça XV, no centro da capital fluminense. As quatro varas foram transferidas para suas "novas instalações" no ano de 2012, mais precisamente no dia 12 de junho do referido ano. Antes da reforma, estavam divididas entre dois prédios. A $1^{\text {a }}$ Vara realizava seus julgamentos no local conhecido como Palácio da Justiça $^{3}$ e as demais funcionavam nesse mesmo prédio principal, no Foro Central, porém em outro andar.

As Varas do Júri, então, foram todas reunidas no prédio principal. Para recebê-las o judiciário fluminense criou uma nova estrutura física ${ }^{4}$ composta de plenários, plateia e respectivos gabinetes. Esse espaço foi modernizado e, além de ser construído com materiais

\footnotetext{
${ }^{2} \mathrm{O}$ presente trabalho integra reflexão mais ampla, presente em minha tese de doutorado, defendida em janeiro de 2018 no âmbito do Programa de Pós-Graduação em Antropologia da Universidade Federal Fluminense, e que consiste em uma etnografia que tem como campo empírico a administração de conflitos em uma Vara do Tribunal do Júri da Comarca do Rio de Janeiro. Isto é, a partir de observação e descrição densa, busquei analisar as peculiaridades deste fenômeno que acontece naquele espaço, ao tentar compreender os sentidos e os significados das práticas dos agentes que ali atuam. Trata-se, pois, da escrita de uma etnografia sobre o "fazer judicial" (EILBAUM, 2012) que acontece cotidiana e diariamente no Tribunal do Júri.

3 O hoje chamado de "Museu da Justiça do Estado do Rio de Janeiro" localiza-se próximo ao Foro Central. O prédio foi inaugurado em 6 de novembro de 1926 com a finalidade de abrigar a então chamada "Corte de Apelação". Durante mais de oito décadas esse espaço abrigou várias Varas e Tribunais, inclusive o Tribunal do Júri. Tal construção, depois de passar por uma reforma nos anos de 2009 e 2010, passou a abrigar o referido Museu. É nessa construção que existe o "Salão dos Passos Perdidos".

4 Conforme notícia veiculada no site do Tribunal de Justiça, TRIBUNAL DE JUSTIÇA DO RIO DE JANEIRO. Disponível em: <http://portaltj.tjrj.jus.br/web/guest/home/-/noticias/visualizar/79501>. Acesso em 28, ago., 2014.
} 
nobres como mogno, granito, vidros blindados e espelhados, foi também equipado com muitos aparelhos eletrônicos como câmeras, microfones e computadores, dando ao lugar, aos meus olhos, isto é, na minha representação, características de luxo e riqueza. Além disso, a sua estética contrasta com outros Tribunais do Júri de comarcas que conheci, no estado do Rio de Janeiro e fora dele, e também com outras partes do próprio Foro Central.

O Foro Central, aliás, é dividido entre a parte "antiga" e a "nova". A antiga tem o piso acinzentado, com banquetas de corino ${ }^{5}$ preto envelhecidas e corredores escuros. Na estrutura do Júri, somente os cartórios das Varas, que se afiguram em espaços de menor prestígio dentro da hierarquia do trabalho judiciário, ainda estão situados na "lâmina antiga", no nono andar. As demais instalações (plenários e gabinetes) ficam na "parte nova".

Impressão semelhante a que eu tinha, certa vez foi expressa por dois jurados que, sentados ao meu lado antes do início de uma uma sessão de julgamento, travavam uma conversa entre eles. Durante o diálogo, um dizia ao outro: "o quanto não gastaram nisso tudo aqui, enquanto tem tanto hospital sem leito". O comentário do homem me remeteu para o retrato de um local luxuoso, exatamente o que pensei na primeira vez em que lá estive. Não por acaso essa percepção era enunciada por um jurado e não por um integrante da família judicial ${ }^{6}$.

Assim, cada uma das quatro Varas do Júri dispõe de uma estrutura exclusiva, com o respectivo plenário e sua plateia. Essa também se afigura em uma inovação resultante da reforma acima citada, pois antes havia apenas um plenário no prédio em que hoje funciona o museu e outro no edifício principal. Este último era compartilhado pelas três Varas lá localizadas, que alternavam seus julgamentos.

Além das sessões, duas Varas realizam as "audiências de instrução" dentro desses recintos amplos, que são abertos ao público. Nas outras duas, por decisão tomada por seus

\footnotetext{
5 Corino é um material sintético que imita couro. Considerado mais ecológico também é de custo inferior. Feito com tecido $70 \%$ de PVC, $25 \%$ poliéster e $5 \%$ poliuretano. Possui, portanto, tipos de plástico em sua composição, para ficar mais semelhante ao couro natural. Vide, para mais informações: <https://www.westwing.com.br/guiar/corino/>. Acesso em: 23, dez., 2017.

${ }^{6}$ Esta é a categoria analítica que uso, em diálogo com o trabalho de SIRIMARCO, 2013 e SARRABAYROUSE, 1998. O termo "família" era utilizado pelos meus interlocutores, também se afigurando em uma categoria nativa. No que se refere à categoria analítica, em meu contexto de pesquisa o sentido dado ao termo família, no que se refere às relações estabelecidas entre os agentes do estado, surgia principalmente nas falas proferidas durante os discursos formais, quando eles apontavam: "aqui dentro vivemos numa espécie de família, embora desempenhemos funções antagônicas". Notei então que essa família se referia a um sentido ideológico, não consanguíneo, do termo e tinha uma função aglutinadora naquele grupo. No que concerne à família judicial, o magistrado era claro: "Somos amigos, somos uma família".
} 
respectivos juízes titulares, foram criadas "salas de audiências", no local inicialmente projetado para funcionarem as "salas secretas". Assim, em tais Varas os julgamentos e as audiências podem ocorrer concomitantemente: em dias de julgamento, as audiências ocorrem na sala secreta. Quando os jurados vão votar, suspendem os atos processuais de "instrução" e fazem as votações. Depois disso, as audiências são retomadas.

$\mathrm{Eu}$, habitualmente, ficava no oitavo andar, pois desenvolvi a pesquisa essencialmente junto aos agentes responsáveis pelo fazer judicial. Por isso costumava me dirigir diretamente para lá, depois de ingressar por uma das portarias do prédio. Explico isso porque o espaço onde acontecem as sessões e audiências tem dupla entrada: uma pelo oitavo andar, destinada às partes que estarão presentes na audiência (vítimas e réus), juiz, promotores, defensores, advogados e testemunhas; e outra separada, no nono andar. Esta última foi projetada para receber o público que integra a "plateia". Configura-se, assim, uma separação espacial entre aqueles que vão assistir o júri e aqueles que vão fazer a sessão acontecer.

A plateia fica no nono andar, apartada e ao mesmo tempo interligada, do/ao plenário por grandes vidros que são blindados, segundo o policial militar que faz a segurança do plenário. Há diferença de altura entre os espaços, o que produz um desnível físico e visual entre os ambientes e dá ao conjunto a configuração de auditório em declive, que pode ser associado com a planta de um "cinema" ou de um "teatro".

Em cima permanecem sentados os familiares das vítimas e dos réus, assim como os demais interessados em assistir ao julgamento. No andar de baixo, juiz, promotor, advogados ou defensor e seus respectivos assessores, bem como os guardas e o oficial de justiça fazem os atos judiciais. O réu e as testemunhas também ficam no andar de baixo, pois é ali que acontece o julgamento. Estas últimas, depois de prestarem depoimento podem ir embora ou subir para assistir a sessão na plateia. O réu, por sua vez, permanece em plenário na maior parte do tempo, salvo quando os trabalhos são suspensos ou quando uma testemunha pede para não depor em sua presença. Essa segunda opção é relativamente frequente, e se dá quando os envolvidos alegam "temor ou sério constrangimento"7 em relação ao acusado. Nesses casos o réu é retirado do plenário e espera na carceragem, enquanto tais testemunhas são ouvidas.

\footnotetext{
${ }^{7}$ Dispõe o artigo 217 do Código de Processo Penal que "Se o juiz verificar que a presença do réu poderá causar humilhação, temor, ou sério constrangimento à testemunha ou ao ofendido, de modo que prejudique a verdade do depoimento, fará a inquirição por videoconferência e, somente na impossibilidade dessa forma, determinará a retirada do réu, prosseguindo na inquirição, com a presença do seu defensor.
} 
O policial militar referido acima, em conversa com familiares de um réu que queriam assistir a uma sessão, lhes orientou que fossem ao andar de cima. Em seguida, lhes explicou: “é como se fosse um cinema, lá vocês podem sentar e assistir ao julgamento". Chamo a primeira sala, que pode ser acessada e está localizada no $8^{\circ}$ andar de "plenário", pois nela acontecem os rituais judiciais, isto é, as audiências e julgamentos. A "plateia” é a sala localizada no $9^{\circ}$ andar, pois é neste piso que o público pode assistir às sessões. Essas também são as categorias usadas pelos agentes para denominar ambos espaços. Abaixo inseri uma foto que traz a visão que o magistrado tem, quando sentado em sua cadeira, ao observar a plateia.

Foto 1 - Vista do lugar do Magistrado

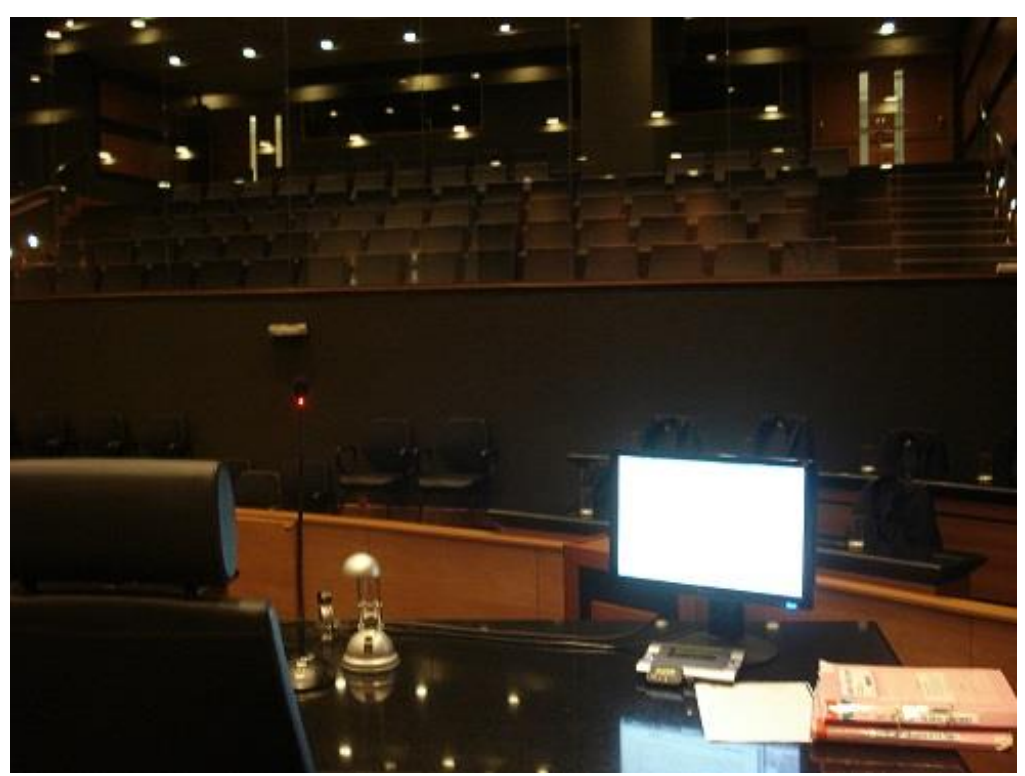

Fonte: Nuñez, 2015.

Os familiares e todos os demais interessados em acompanhar os julgamentos (jornalistas, estagiários, estudantes, pesquisadores, entre outros) são proibidos de se acomodarem na primeira fileira de cadeiras da plateia, que pode ser visualizada na foto acima. Segundo o juiz, "sentar naquela distância ameaça a segurança dos jurados". Disse-me à oportunidade que eles poderiam ser vistos por quem está assistindo o julgamento desse lugar, mas não das fileiras posteriores. Porém, mesmo nos dias em que são realizadas audiências de instrução e julgamento, isto é, quando não há jurados presentes, a interdição do público acomodar-se na fileira mais próxima aos vidros é mantida. 
A referência do policial sobre o cinema remete também a outro elemento que, ao olhar da plateia para o plenário, ganha destaque: a existência de um telão, que fica afixado na parede do oitavo andar, e pode ser facilmente visualizado por todos que estão no andar de cima. Este equipamento reproduz imagens do plenário. O telão, que salta aos olhos de quem está no piso superior, transmite apenas as imagens de quem está depondo (testemunhas e réus). Durante as sustentações, a câmera registra o piso inferior, em plano aberto, sem filmar os jurados. Há também caixas de som presas na parede do nono andar, que, quando ligadas, reproduzem o que foi dito no plenário para os que assistem a sessão. Abaixo trago um registro da visão que aqueles que estão na plateia têm, quando observam o plenário. O vidro "blindado" os separa fisicamente da família judicial.

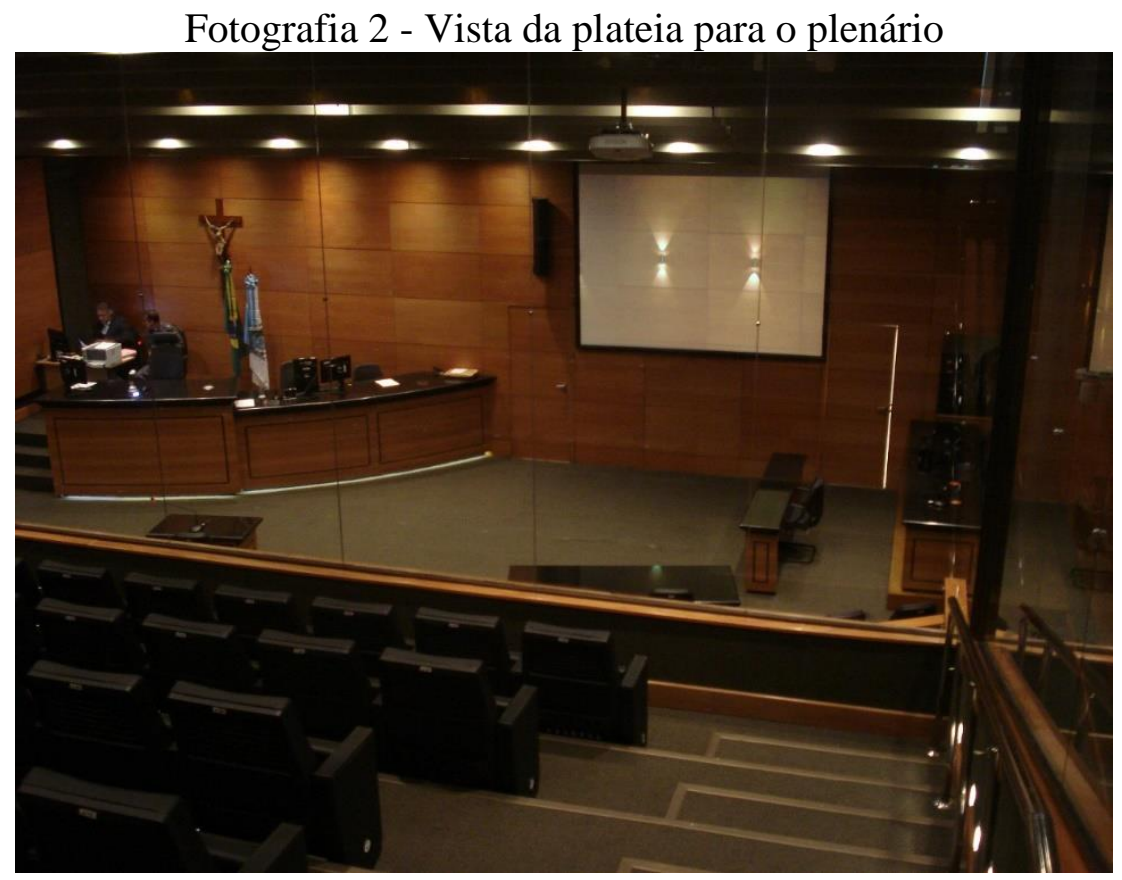

Fonte: Nuñez, 2015

Na foto acima, a mesa estreita, localizada mais próxima ao telão e sem microfone é onde permanece o réu durante o julgamento, voltado para o juiz e de costas para seus defensores. A porta à esquerda da mesa é por onde entram os jurados e demais agentes. Já a porta à direita permite acessar a sala de testemunhas. Da plateia não se vê os jurados, pois eles ficam sentados próximos à parede oposta ao telão, diante do juiz, como melhor demonstra a imagem inserida a seguir (fotografia 4). Os presentes no andar de cima observam diretamente o magistrado e o 
promotor. Tanto os acusados quando interrogados, quanto as testemunhas quando vão depor, acomodam-se na mesa menor, em frente ao magistrado, que conta com um microfone e também pode ser vista na foto acima. Este móvel fica de costas para o público e para os jurados. Tal disposição contrasta com a das salas de julgamento americanas, nas quais as testemunhas ficam de frente para o público.

Abaixo, insertei fotografia panorâmica, tirada de dentro do plenário. As cadeiras onde estava quando capturei a imagem são ocupadas pelos jurados, antes da realização do sorteio, enquanto aguardam pelo início da sessão. Na foto, à esquerda, estão os assentos preenchidos pelos sorteados e, diante deles, a mesa com microfone, é aquela na qual sentam réus e testemunhas para depor. No registro é possível visualizar o policial militar, responsável pela segurança do plenário, ao fundo da imagem. Não havia sessão quando fiz as fotos, por isso o ambiente estava vazio e também por este motivo fui autorizada a fazer tais registros.

Fotografia 3- Vista das cadeiras localizadas ao fundo do plenário voltadas para o juiz

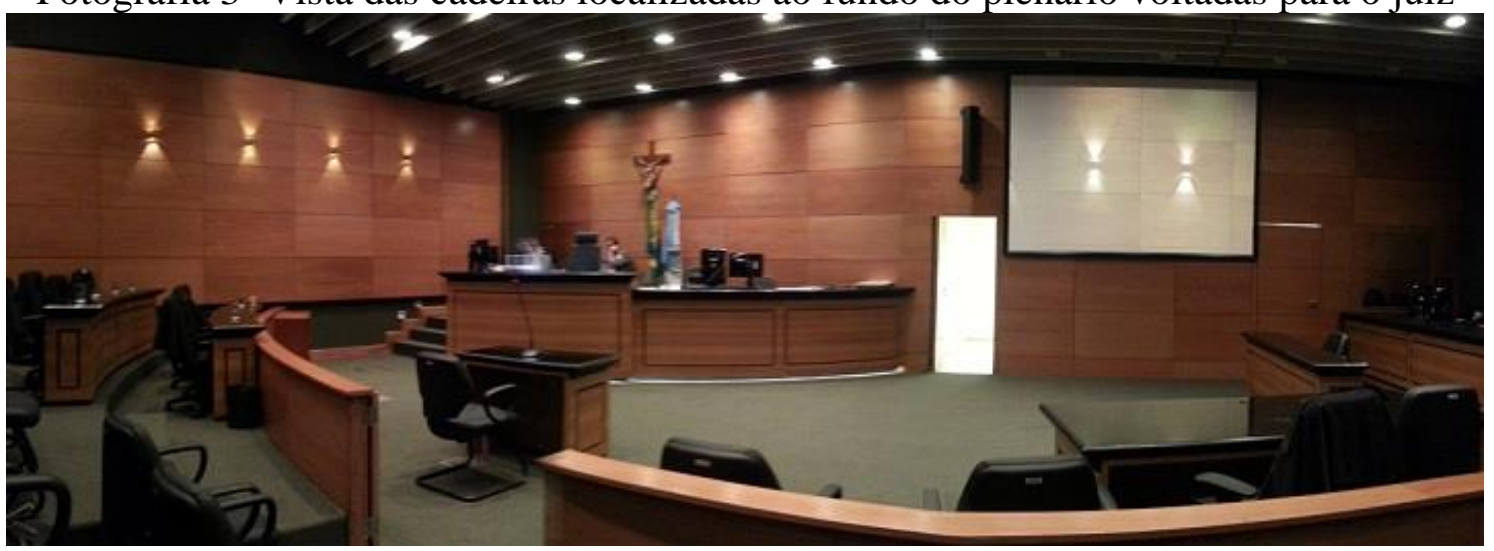

Fonte: Nuñez, 2015

O lugar ocupado por mim no recinto variou ao longo da pesquisa. No começo acompanhava as sessões ao lado do defensor, pois foi através do contato estabelecido com ele que iniciei o trabalho de campo. Posteriormente, passei a me relacionar com os demais agentes e assistia os atos judiciais no local de onde fiz o registro fotográfico acima. Sentava nessas cadeiras, localizadas em frente à porta que dá acesso ao plenário, ao lado dos jurados sorteados e atrás da mesa do oficial de justiça, portanto longe do juiz. 
Por fim, com a mudança do magistrado titular, acompanhei muitas sessões ao lado da promotora, do novo juiz e de seus respectivos assessores. Apenas uma vez sentei na mesa destinada aos jurados, por convite do defensor, enquanto se desenrolava uma série de audiências. Em outra oportunidade, o juiz substituto convidou-me a sentar na mesa dos jurados para "experimentar” a sensação de estar lá. Quanto à minha presença naquele recinto, não houve autorização formal para acompanhar os trabalhos no plenário, porque nunca foi demandada uma conversa com o magistrado, pedindo sua aprovação para lá permanecer. No entanto, perguntei se poderia fazer as fotos e fui por ele autorizada a tanto.

\section{O PLENÁRIO: O LUGAR POR EXCELÊNCIA DO RITUAL JUDICIÁRIO}

O espaço do plenário é delimitado de modo estanque. Os lugares ocupados pelos agentes são claramente circunscritos. Há um afastamento espacial nítido entre eles: juiz, promotor e defensor ou advogado. Todos têm as suas posições previamente estabelecidas e alterar esses lugares, além de muitas vezes não ser permitido, quando o é, pode causar desconforto entre os presentes. Acompanhei um episódio que demonstrou essa demarcação do espaço. A ocorrência envolveu um defensor público, titular de outra vara, que excepcionalmente realizava uma audiência no tribunal em que eu fazia pesquisa de campo. Durante o ato, o homem levantou-se de seu lugar e aproximou-se da mesa onde as testemunhas são colocadas, para fazer perguntas a um depoente. Nesse momento o juiz o repreendeu, pedindo que retornasse a sua mesa e fizesse as indagações de lá, reafirmando assim a divisão espacial. O magistrado, assim, demonstrou seu controle sobre o espaço e o contato das partes com as testemunhas. Sua ingerência, exercida de modo inquisitorial, impossibilita a existência de qualquer caráter adversarial nesse ato ${ }^{8}$

8 A oposição de modelos judiciários que buscam o consenso (lógica adversária) e modelos fundados no dissenso (lógica do contraditório) é importante para a compreensão da produção da verdade no caso brasileiro. Na primeira, adversarial, o saber particularizado deve ser neutralizado, ou até mesmo criminalizado, quando utilizado em público. Na segunda, a lógica do contraditório "o saber particularizado converte-se em poder em público e tem sinal positivo: quem está no vértice da pirâmide - de qualquer pirâmide (social, econômica, política, judiciária etc.) - exerce seu poder fundado no saber de que se apropriou particularizadamente, ao qual não tiveram acesso seus pares, pois pode inclusive dele se apropriar por meio de suas relações particulares" (KANT DE LIMA, 2010, p. 43). No Brasil, as provas ficam sujeitas a esse segundo modelo, o que reflete na maneira como o juiz trata as testemunhas e os agentes, durante a oitiva dos depoentes. Assim, evidencia-se que a prova não pertence às partes (como no sistema acusatório) mas ao magistrado (próprio do sistema inquisitorial) . 
(KANT DE LIMA, 2010, p. 43) demonstrando explicitamente à noção de pertença das testemunhas ao juiz.

Como disse, o magistrado é a figura central desse espaço. E essa centralidade pode ser percebida tanto de dentro do plenário, quanto em relação à vista que a plateia tem do ambiente. Desse modo, tal organização espacial contraria a ideia comumente veiculada nos livros de doutrina jurídica de que o júri é feito para os jurados. A representação no direito, de que este é um "tribunal popular" no qual os "juízes leigos" têm protagonismo, se confronta com a organização física do Júri como um todo e, também, do plenário. A forma como o espaço está ordenado indica que não são os jurados a parte fundamental do ambiente. Na prática, o foco e a centralidade são do magistrado, pois todos os presentes para ele se voltam. De seu assento, que é o mais alto do recinto, é possível manter o controle visual sobre todo o espaço (vide fotografia 1). É nesse lugar que o juiz passa a maior parte do tempo que transcorrem as sessões e audiências.

Como se vê na foto panorâmica abaixo, ele consegue observar todo o tribunal. Pode assim analisar as pessoas sentadas na plateia, bem como todos os presentes no plenário. Além do controle visual, tem autoridade para pedir que os espectadores se retirem e permitir ou restringir as entradas e saídas do plenário. Também, de acordo com o CPP, é o responsável por "manter a ordem" do local, tanto em relação aos que assistem, quanto em relação aos que participam dos julgamentos 9 .

Fotografia 4 - Vista panorâmica da mesa do juiz sobre todo o espaço

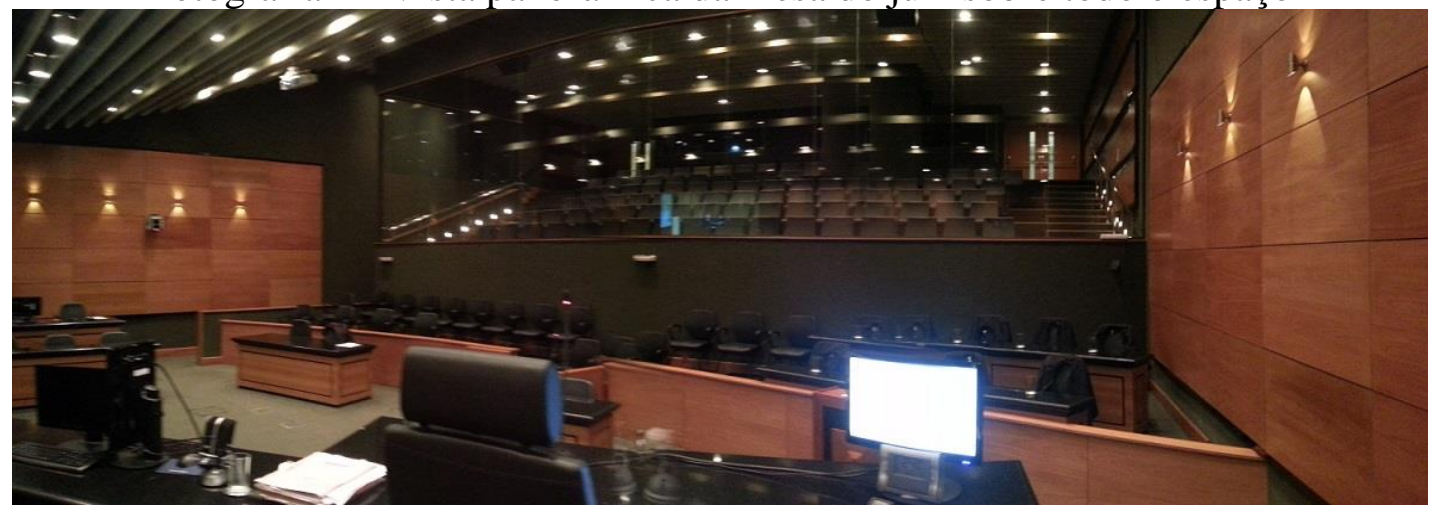

Fonte: Nuñez, 2015.

9 Dispõe o artigo 497 do Código de Processo Penal que "São atribuições do juiz presidente do Tribunal do Júri, além de outras expressamente referidas neste Código: I - regular a polícia das sessões e prender os desobedientes”. 
Como se vê na imagem acima, à frente do magistrado ficam as duas bancadas e as cadeiras destinadas aos jurados. Nessas fileiras sentam os sete sorteados para a realização da sessão de julgamento do dia, sendo quatro na fileira de trás e três na da frente (vide fotografia 4). Os jurados ficam de costas para o público, não sendo possível vê-los da plateia, a não ser quando entram ou quando saem do plenário (vide fotografia 2). As mesas onde sentam situamse em um nível abaixo do andar onde está a plateia, como demonstra a foto acima. Suas cadeiras, também visualizadas na referida imagem, estão cobertas com as capas que usam enquanto realizam o julgamento.

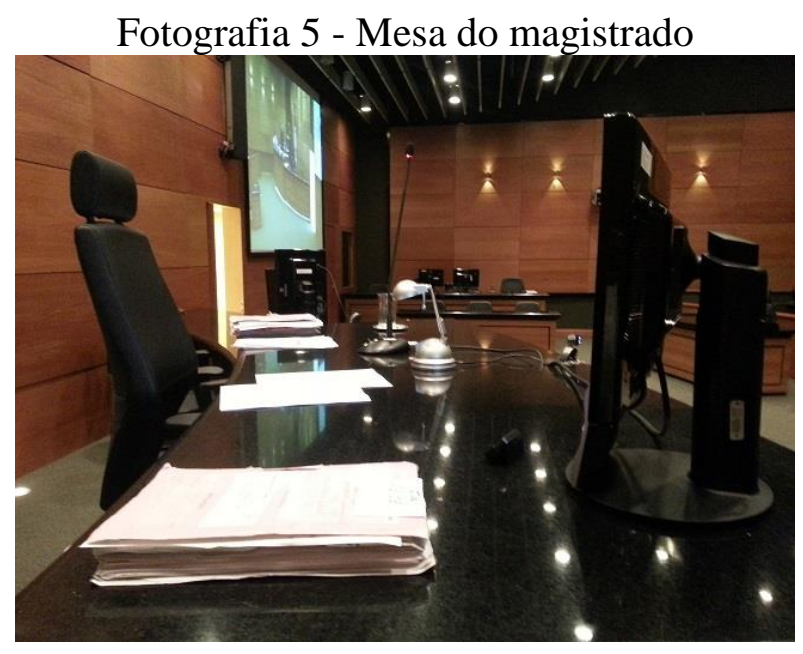

Fonte: Nuñez, 2015

A imagem acima apresenta a mesa do magistrado registrada lateralmente. Ao fundo dela, à esquerda, está o telão afixado na parede, que referi anteriormente. Mais ao fundo, em frente, está a mesa do réu, seguida da mesa da defesa. Do lado oposto de onde esta foto foi tirada, ao lado esquerdo do juiz, fica a mesa da acusação. Diante de cada um, acusação e juiz, há um computador e um microfone. Este último serve para capturar as falas de ambos, que podem ligá-lo e desligá-lo, além de ser controlado pelo técnico de som, que fica ao fundo da plateia, no nono andar.

Juiz, promotora e secretário do juiz, ficam sentados neste estrado mais alto, que forma um semicírculo, localizado no canto direito da sala, de frente para a plateia e que pode ser visto nas fotografias 2 e 3 . Atrás do magistrado e da mesa destinada à acusação, nas mesmas imagens 
supracitadas, nota-se que foi afixada uma grande cruz, de mais de um metro e meio, assim como as bandeiras do estado do Rio de Janeiro e do Brasil.

A acusação, embora também permaneça no estrado, ficava em altura mais baixa que o juiz. Um promotor de justiça que atuava em outro tribunal, em conversa informal comigo, certa vez chamou minha atenção para o posicionamento da acusação no Júri da Capital. Segundo me disse, se "aqui fica à esquerda", no interior, diferentemente, "fica à direita" do juiz. Na sala onde funcionava o Júri antigamente, no prédio que hoje é o Museu da Justiça, igualmente. O MP ficava à direita do magistrado.

Durante o trabalho de campo, conversei com diversos agentes sobre a organização física do plenário da capital. Dentre eles, destaco as impressões de Esmeralda, uma defensora pública "antiga" na carreira. Ela, depois de ter atuado por doze anos como titular do Júri, pediu remoção da vaga e foi exercer suas funções em uma Vara Criminal Comum. Entre os motivos, dizia-me, estava a nova configuração espacial do plenário. Quando fiz a pesquisa, embora ela não trabalhasse mais lá, frequentemente visitava seus colegas em dias de sessão. Durante nossas conversas, destacava que a nova configuração havia reforçado a centralidade da figura do magistrado e assim mencionava seu incômodo com essa posição. Dizia-me então que o juiz tinha se tornado definitivamente o centro do julgamento, pois os jurados foram afastados do âmago da cena. Para ela, se antes as testemunhas e os réus depunham voltados para os jurados, agora todos os presentes ficam direcionados apenas para o juiz e para a acusação que, afinal, fica ao seu lado.

\footnotetext{
O juiz é o centro do Júri hoje, e não mais o conselho [de sentença]. Os jurados não enxergam o réu, ficam diante do juiz, de lado para a defesa. Os jurados ficam voltados para o juiz. $\mathrm{O}$ acusado, quando vai depor, fica de costas para eles, sem que possam ver o que o réu e as testemunhas estão dizendo. Isso é um problema porque um depoimento é mais que uma foto $3 \times 4$, a pessoa fala com os olhos, com o corpo, com a voz, com a maneira que mexe o pé. O júri, como está atualmente, perde isso. (Defensora Pública).
}

A foto seguinte registra a visão que defensor (ou advogado) e réu têm do espaço, pois foi tirada enquanto estava sentada à mesa da defesa. A imagem permite ver o desnível entre os lugares destinados ao juiz e à acusação, bem como a proximidade entre eles. Ao fundo, é possível visualizar as mesas dos jurados e, antes delas, a mesa de colheita dos depoimentos e 
interrogatórios. O registro demonstra o quanto defensor e réu ficam afastados dos demais atores, especialmente dos jurados, que se situam no extremo oposto da sala, exatamente como pontuou a defensora na conversa que transcrevi acima.

Fotografia 6 - Mesa na qual sentam testemunhas e réu para depor e ser interrogado, respectivamente

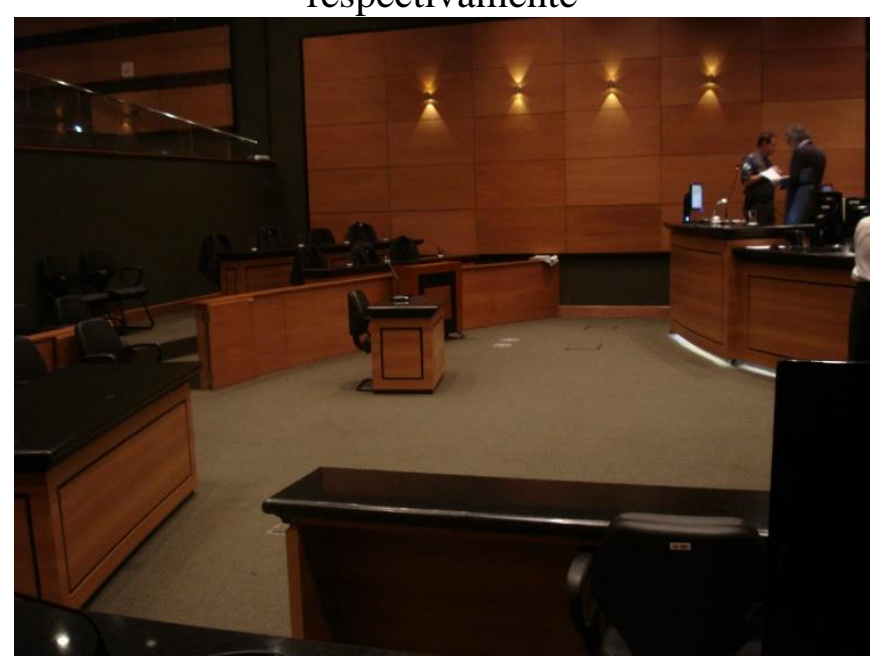

Fonte: Nuñez, 2015

Em relação à entrada do plenário, a defesa fica ao lado esquerdo de quem ingressa no recinto, assim como à esquerda do juiz. Na perspectiva da plateia, a tribuna defensiva é vista lateralmente (vide fotografias 2 e 3). No móvel onde se sentam os membros da defesa também há dois microfones e dois computadores, assim como nas mesas do juiz e da acusação. Diante dela, está colocada a mesa do réu. Abaixo inseri outro registro que traz as imagens dos assentos do réu e de seu defensor. Atrás, presa à parede, está a câmera que filma o plenário e cujas imagens são transmitidas no telão. 


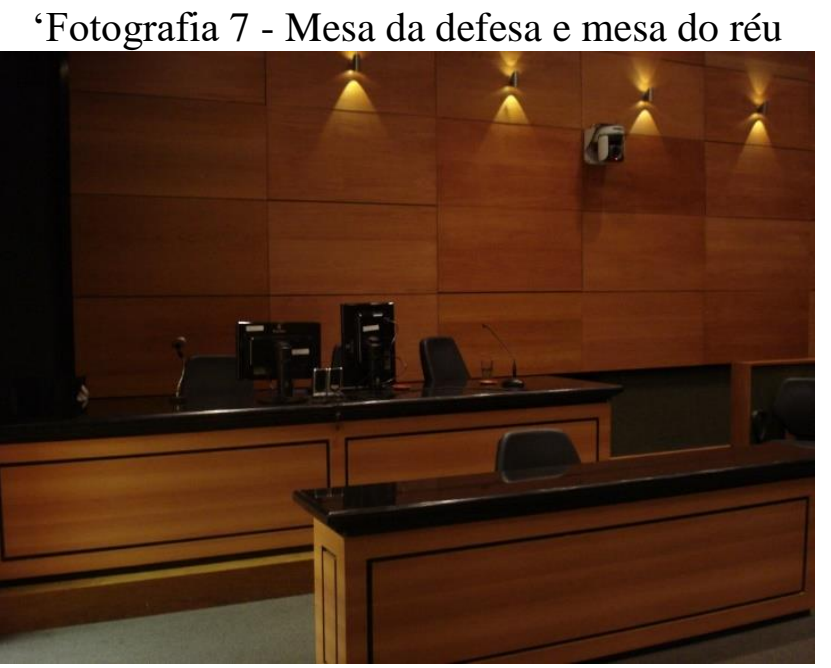

Fonte: Nuñez, 2015.

Os agentes do poder judiciário carioca, ao organizarem o espaço dessa forma, reforçaram traços do procedimento do júri que já existiam e, ainda, produziram novos resultados que merecem ser destacados. Primeiramente ressalto a proximidade entre o Ministério Público e o juiz, que foi acentuada, pois o promotor foi elevado a uma altura superior à posição defensiva e, ainda, colocado em frente aos jurados. Além disso, manteve-se a possibilidade de que ambos conversem e troquem informações a todo o momento, inclusive durante os turnos de fala da defesa, enquanto esta faz a sua performance durante o ritual. Como o juiz pode se pronunciar e fazer perguntas às testemunhas e réus a qualquer tempo, depois dessas conversas que trava com a acusação, o magistrado frequentemente volta a indagá-los.

A defesa não recebe o mesmo tratamento, e nem poderia, pois está espacialmente muito distante do juiz. As conversas com os demais agentes ficam dificultadas, pois os defensores e advogados permanecem isolados dos demais. Assim, eles foram ainda mais separados. Afastando-os, por consequência, da comunicação estabelecida entre promotor e juiz e também dos jurados. Inclusive, durante os julgamentos, os defensores precisam levantar de seus lugares para que possam conversar com o magistrado, com o secretário dele ou com o membro do MP, porque é impossível fazê-lo de outro modo.

Essa configuração do plenário explicita, portanto, as desigualdades e a hierarquia no tratamento dispensado às partes, isto é, aos agentes que fazem o julgamento. $\mathrm{O}$ espaço físico, tal como está organizado, reflete uma concepção de produção de justiça. A acusação, permanece 
sentada ao lado do juiz e fica em posição superior à defesa, inclusive quanto à altura de seu assento, pois o tablado onde sua mesa está colocada é mais alto. O réu e seu defensor, foram ainda mais afastados do centro de poder. Ficam posicionados de lado, distantes das dinâmicas que acontecem perto dos jurados. Estes últimos, por sua vez, ficam subordinados às falas e expressões do magistrado e da acusação. Retira-se assim qualquer organização "adversarial" do espaço, que é aquela em que se delega às partes a produção consensual da verdade jurídica, buscando a solução do conflito através da consensualização e da argumentação (FERREIRA, 2013, p. 224).

Se contrastarmos esta disposição com a das Courtrooms americanas, a inquisitorialidade brasileira ganha ainda mais realce. Nos Estados Unidos, onde o caso será decidido a partir da produção de uma decisão unânime, elaborada pelos doze jurados, a prova é produzida de frente para eles, diante dos cidadãos. As testemunhas, nas cortes americanas, sentam-se também nessa posição em relação aos jurados, sentados ao lado do juiz. No Brasil, ao contrário, o depoente fica de costas para o conselho de sentença e diante do magistrado. Este, por sua vez, foi abancado em um tablado e, por isso, mais alto do que aquela pessoa que está sendo questionada. Além disso, no cenário americano, como a prova é produzida pelas partes, acusação e defesa sentam-se lado a lado, em posição de igualdade, em frente ao magistrado e as testemunhas, traduzindo assim espacialmente a "igualdade ideológica" entre elas (KANT DE LIMA, 2009, p. 186). Lá, o centro do julgamento são os jurados, responsáveis por proferir a decisão.

Logo, nessa configuração, a figura do juiz como centro de poder, como autoridade e para quem todos no ambiente devem se voltar fica ainda mais explícita. Destaco tal elemento porque, a partir dele, a inquisitorialidade do processo penal brasileiro (KANT DE LIMA, 2009) se revela e se reforça ainda mais no Júri e traduz-se visualmente desde a sua configuração espacial. A divisão dos lugares é evidente. O controle do processo pelo magistrado, e não pela acusação e defesa, é perceptível também pela organização física do plenário.

Em conversa informal com um dos magistrados que atuou temporariamente no Júri, ele comentou comigo que não fazia perguntas às vítimas porque "todo mundo presta atenção no juiz”. Segundo me disse, tudo que fosse por ele perguntado poderia influenciar a opinião dos jurados. Falou-me então que procurava "não ser incisivo com a vítima, por que a vítima é quem carrega a emoção". No entanto, mesmo sabedor dessa "influência”, Gustavo fazia perguntas imperativas aos réus. Além disso, contraditava as versões dos fatos apresentadas pelos acusados e, durante todo o julgamento, produzia expressões faciais e verbais de contrariedade, quando 
aborrecido. Tais manifestações permitiam perceber os juízos que ele fazia sobre os casos que estavam em julgamento.

Em terceiro lugar, os jurados. Eles, embora sejam os responsáveis pela produção da decisão acerca da condenação ou absolvição do réu, perderam o contato direto com a "prova oral" produzida em plenário. Isso porque, como descrevi acima, não conseguem observar os depoentes ou interrogados face a face e não podem "apreciar a produção de provas" diretamente, pois não enxergam as testemunhas e os acusados. Estes últimos, assim como os jurados, ficam voltados para o magistrado. O conselho de sentença, a seu turno, também fica voltado para o juiz. De modo que, como pude perceber, eles buscavam observar as suas expressões, tanto durante os debates quanto em todas as demais fases do julgamento em plenário. Por fim, com a inserção do vidro blindado, vem a inovação definitiva: o público é concretamente apartado da cena de julgamento. Não mais fazendo parte do ritual do Tribunal do Júri, senão como mero expectador.

Assim, destaco finalmente que a hierarquização se reflete especialmente no isolamento dos jurados. Essa que, como disse, talvez seja a maior inovação trazida pela reforma espacial do Tribunal do Júri da Comarca do Rio de Janeiro. Eles são apartados da plateia, pois permanecem de costas para o vidro, em andar mais baixo. E, ainda, são colocados diante do juiz. De modo que não podem observar as reações do público ao que está sendo dito no andar inferior. $\mathrm{O}$ vidro forma, em torno do plenário, localizado no andar de baixo, uma espécie de aquário. Isola-o acusticamente do andar de cima, onde fica o público. Com esse afastamento não há mistura moral entre as reações da plateia e o veredito proferido pelos jurados. Nesse sentido, os "jurados” que supostamente representariam a "participação popular" na justiça, são isolados da "sociedade" na forma do público.

O espaço, tal como ele é organizado e experimentado pelos agentes do judiciário e pelas pessoas que por ele circulam, reflete, portanto, os sistemas classificatórios que constroem o fazer judicial, uma vez que "a classificação das coisas reproduz a classificação dos homens" (DURKHEIM e MAUSS, 2009, p. 405). Além disso, considerando que toda classificação implica, consequentemente, numa hierarquização (DUMONT, 1997, p. 373), essa forma de lidar com o lugar explicita as desigualdades e hierarquias no procedimento do Tribunal do Júri. 
Isso porque, o ambiente no qual o julgamento acontece, também pode ser visto como uma expressão concreta dos ideais de justiça ${ }^{10}$ locais (MULCAHY, 2007, p. 383).

Durante as sessões, os agentes e jurados são separados da plateia, demarcando-se assim o lugar por excelência da família judicial, em contraposição àquele destinado ao "público". Os usos dos espaços também revelam os limites comportamentais do "público" e dos agentes do judiciário, delimitando formas de estar naquele lugar. Enquanto na plateia não se pode comer, nem beber, os agentes são livres para fazê-lo, assim como para usar equipamentos eletrônicos e celulares.

A separação da plateia dos agentes, estabelece quem pode e quem não pode fazer parte do processo de fazer justiça. Ainda, importante destacar que é pelo olhar dos agentes, e não pelos próprios jurados, que a plateia e suas reações aparecem durante os julgamentos. Com isso, os o conselho de sentença fica isolado e protegido do "público", de modo que não seja “influenciado" durante o julgamento. O juiz, é o centro do poder e do procedimento, fica espacialmente no cerne do espaço, de onde comanda tudo e todos. Suas reações são observadas por todos no recinto. A posição, ainda, traduz visualmente a inquisitorialidade (KANT DE LIMA, 2009) própria do sistema de justiça criminal brasileiro.

Além disso, a forma como está estruturado, reflete a representação de "participação popular na justiça" no caso brasileiro: o afastamento da plateia e do povo. Esta concepção, de acordo com os juristas, é a premissa a partir da qual o júri se assenta. Os "doutrinadores” do Direito o classificam como uma "instituição democrática" ou a "expressão processual mais popular da aplicação do direito penal substantivo" (BONFIM, 2000, p. 33) porque conta com jurados para a produção da decisão e com a presença do público. O espaço, no entanto, conforme está estruturado, afasta toda e qualquer participação popular ou democrática e, ainda, organiza-o de forma que isola o conselho de sentença da plateia, inibindo o contato deles com as reações e manifestações do público. Reflete, assim, a representação sobre o que de fato é considerado como "participação popular" na justiça. Ainda, face ao papel central do magistrado, esse último se afigura em um mediador entre os jurados e os mundos dos

10 O artigo de Linda Mulcahy (2007) explora como o uso do espaço na sala de audiências ao longo da história das cortes inglesas está relacionado com o desaparecimento do público no julgamento. Considera como o espaço dentro dos tribunais, incluindo a redução de sala de audiências e ampliação do número de gabinetes, cartórios, bibliotecas e salas para uso dos agentes do poder judiciário, fala sobre a relação entre as várias partes envolvidas num julgamento. A autora conclui que o espaço destinado ao público passou a ser associado com perigo e coloca aqueles que vêm assistir aos julgamentos sob vigilância do juiz. Que passa a ser central nos rituais. 
envolvidos (réu, vítima, testemunhas), tanto o mundo do público quanto o mundo dos autos. O que é visto pelos jurados é, nesse sentido, filtrado pelos agentes do poder judiciário e, em especial, filtrado pelo juiz.

O "vidro blindado" traduz o lugar dado ao público: de meros expectadores. O sentido que lhes é atribuído não é de "participantes", mas de "observadores". E assim não permite que os primeiros - os jurados - sejam afetados pela presença ou manifestação dos últimos - os presentes na plateia. Sua presença não é sequer a mesma da plateia em um teatro, pois os jurados não estão sujeitos às suas reações. A plateia tem a função de legitimar um processo, não de "participação popular".

Relaciono, por fim, o vidro do plenário com outro, que foi colocado na Câmara dos Deputados, em Brasília, no ano de 1993, depois da ocorrência de uma votação na qual manifestantes atiraram moedas e notas sobre os deputados. No ano de 2004, depois de diversas declarações contrárias à existência do vidro, ele foi retirado. O presidente da Câmara à época da remoção, deputado João Paulo Cunha (PT/SP), disse que sua decisão serviria "como símbolo do reencontro da Câmara com o povo, que quer acompanhar os trabalhos dos deputados ${ }^{11 "}$. Nesse sentido, a representação do afastamento imposto pelo vidro é evidenciada na fala do deputado. O mesmo pode ser pensado nesse formato do Tribunal do Júri do Rio de Janeiro.

\section{DE TEATRO A CINEMA}

A metáfora do "teatro" e do "cinema", esta última enunciada por meus interlocutores, ajuda a compreender essas mudanças espaciais e o afastamento do público do fazer judicial, no Rio de Janeiro. Quando pensa o Júri como teatro, SCHRITZMEYER (2001) diz que o plenário seria o "palco", ou seja, o espaço em que juiz, promotor e defensor ou advogado fazem o julgamento acontecer. O lugar onde se dá o exercício dramatizado do poder, segundo a autora. No entanto, "teatro" em minha pesquisa, surgiu como categoria nativa e pode ser pensado tanto como encenação e dramatização quanto sobre a relação entre público e plateia. Nesse segundo

11 Vide, para mais informações sobre o vidro e a sua retirada, notícia veiculada pela Empresa Brasileira de Comunicação em seu site: <http://memoria.ebc.com.br/agenciabrasil/noticia/2004-01-05/camara-acaba-comparede-de-vidros-que-separava-plenario-das-galerias $>$. Acesso em: 24, jul., 2018. 
sentido, é adequado para analisar como esta nova configuração do espaço surge como um reflexo das práticas judiciais, ao mesmo tempo que as afeta.

A mesma defensora pública que citei anteriormente, Esmeralda, explicou-me que o juiz titular, durante a execução das reformas para trazer o júri para esse novo espaço, costumava reunir-se com os arquitetos que as projetavam para planejar a nova configuração espacial. Dizia-me que "com esse jeito do [nome do juiz], que vive dizendo que não, ele fazia reuniões com os arquitetos, querendo dar essa cara de teatro para o Júri”. Em seguida ela afirmava, como expus acima, que: “o júri perdeu a graça pois eu media minha sustentação pela plateia, que fazia comentários sobre o que eu estava fazendo". A relação com a audiência, mais próxima, aparecia como algo essencial para minha interlocutora.

Da mesma maneira sentia Evandro Lins e Silva, como se pode ver em entrevista cujo trecho transcrevi abaixo. O público, para esses agentes, estava de fato ligado ao "espetáculo" do júri e influenciava o seu trabalho. O advogado inclusive usa a palavra "torcedores da acusação e da defesa" para referir o "espetáculo sedutor" que ele considerava ser o Júri. A palavra torcedor assemelha-se aos jogos e, em especial, remete as partidas de futebol. Nelas o público apoia, por intermédio dos aplausos ou vaias, as ações dos jogadores, de modo que os atletas profissionais e os torcedores, existem uns para os outros e uns nos outros, como demonstra Damo (2004).

Voltando à relação apontada pela defensora, quanto a medir sua performance de acordo com as reações da plateia, pois sentia-se afetada por ela, também se assemelha com aquela reportada por atores durante a encenação de peças de teatro. A famosa frase de Paulo Autran, de que o "Teatro é a arte do ator e cinema é a arte do diretor" explica como os primeiros são considerados o centro do espetáculo teatral, cuja forma e ordem dependem deles em cena, e o quanto são afetados pelo público, ao longo da execução da peça. Por isso, atores e atrizes afirmam que "cada apresentação é uma”, pois sua execução depende não só do sentimento e do humor do sujeito-ator no dia, mas também das reações da plateia que com ele interage ${ }^{12}$. A defensora, da mesma forma, dizia levar em conta a reação dos ouvintes, ao longo da sua sustentação.

12 Nesse sentido, o teatro é considerado por aqueles que o estudam como a arte da representação do mundo (TAVARES, 2011), que se baseia na cena. O ator representa e o público imagina, dá sentido ao que é encenado. Trata-se de uma "arte pública e para o público". A representação, nesse caso, depende do significado atribuído a ela pelo olhar do sujeito-espectador, que a ela reage. 
O cinema, por outro lado, de tendência realista, traz, na tela uma "apresentação do mundo", a partir do "quadro" e não da cena. O quadro é um recorte, comandando pelo diretor, que ordena e organiza os atores e, depois, comanda também a edição do filme. O cinema é o resultado desse processo, que depois será exibido à plateia. Na tela se pode ver apenas o que o enquadramento permite, exatamente como um recorte, por isso a alusão à "fábula cinematográfica” baseada em uma montagem (TAVARES, 2011). No cinema o público não afeta a obra, ao contrário do teatro.

Assim, a definição nativa, elaborada por parte do policial militar, da nova configuração espacial do Júri como um "cinema” parece fazer sentido e, por isso, explica também como os agentes representam e estabelecem a sua relação com o público. Afastando este último deles e, especialmente, isolando os jurados do último. A hierarquização e a desigualdade se evidenciam em termos espaciais e determinam quem pode e quem não pode fazer parte e influenciar o julgamento.

A referência ao recorte, que é própria do cinema, se mostra na fala do magistrado titular. O mesmo que, segundo a defensora, realizava reuniões para discutir com os arquitetos a estrutura do novo plenário. Aliás, creio que também merece destaque o fato de que, assim como Lins e Silva fala de "torcida", o magistrado menciona a "arquibancada" e o "jogo", também fazendo referência aos esportes e, me parece, especificamente ao futebol. Por fim, seu discurso também explicita o recorte "contextual" que a plateia tem da sessão. Bem como a ideia de proteção do plenário, para manter a "independência" dos jurados. Em entrevista comigo, disseme sobre o novo espaço:

É muito melhor, mais confortável, a qualidade do som é extraordinária, a visão é privilegiada, contextualizada, da sessão. Ficou melhor de assistir, como se fosse uma arquibancada, do que se estivesse ao pé do jogo. (...). Por questões de segurança também, o plenário era muito exposto antigamente. A independência dos jurados é favorecida, ele fica mais protegido. (Entrevista com o Magistrado Titular).

Retomando a ideia de observação e não de participação, ela também é evocada através da fala de outro juiz. Este, que certa vez substituía o titular, disse-me que o "Júri é a vitrine do judiciário". Vitrine, nesse caso, concerne a quem aparece e pode ser visto pela plateia, do outro lado do vidro. Tal qual o cinema, apresenta aos olhos de quem vê, objetos e coisas e, nesse caso, 
pessoas fazendo coisas. A metáfora traz em si duas acepções que, me parece, cabem bem nesse contexto. Por um lado, remete para o que se pode ver, mas não se pode tocar, mexer nem fazer. O que está exposto, mas do que não se participa. Refere-se a quem irrompe do outro lado do vidro, os agentes do judiciário e não o público. Como disse acima, a primeira vez que estive no plenário senti-me exatamente assim, exposta em uma vitrine ou aquário.

Por outro lado, a representação que foi trazida pelo juiz substituto, pode ser pensada como uma exibição do fazer judicial. Aquilo que é exemplar, que é bom. Assim como o Rio de Janeiro foi construído como "vitrine do Brasil" e "Copacabana " a vitrine da cidade, ou seja, como referência, de modo que o Júri traduziria o imaginário sobre o fazer judicial. Para conhecer o judiciário é preciso, portanto, conhecer o Júri. Não à toa, estudantes de direito e os profissionais da área frequentemente param para assistir as sessões, como disse anteriormente. Porque para "aprender" sobre o direito, é preciso observar esse ritual.

O júri, no entanto, era antigamente considerado a "vitrine da advocacia criminal", isto é, do trabalho dos advogados que, ao fazerem as sustentações orais defensivas, iam ficando conhecidos e respeitados. Um bom advogado era afamado em razão da quantidade de júris que havia feito ao longo de sua carreira. Essa compreensão aparece na entrevista de Evandro Lins e Silva, concedida ao CPDOC , sobre a sua trajetória pessoal e profissional. Ele, que foi um dos mais conhecidos advogados criminalistas do Rio de Janeiro, na cidade e no país, pois foi ministro do Supremo Tribunal Federal. Lins e Silva iniciou sua carreira nas décadas de 40 a 60 e, em sua entrevista disse que:

\begin{abstract}
O júri, como se costumava dizer, não dava pão a ninguém, mas podia talvez dar um pouco de glória. Apesar de tudo, exercia um fascínio sobre os advogados, porque era a vitrine do Foro: era ali que o advogado se revelava. No dia em que havia julgamento com advogados famosos, bons expositores, a sala enchia, todo mundo queria assistir ao espetáculo, que é muito interessante, é um drama da vida que se resolve naquele dia, através de um debate entre as partes e, depois, do julgamento secreto dos jurados. Aquilo empolgava a assistência, havia correntes, havia torcedores da acusação e torcedores da defesa. Muitas vezes havia apostas quanto ao resultado, prognósticos: quantos jurados iriam condenar, quantos iriam absolver. O júri era um espetáculo sedutor. Eu me deixei fascinar pelo primeiro julgamento a que assisti e lá fiquei até hoje, não saí mais.
\end{abstract}

O júri, então, depois da reforma e modificação do espaço, foi afastado da influência do público e isolou os jurados e agentes que participam do fazer judicial da sociedade, representada 
por aqueles que vão assistir o ritual de julgamento. Além disso, deixou de ser a "vitrine" da advocacia criminal, utilizada pelos advogados para serem vistos e com isso ganhar clientes e passou a ser a "vitrine do poder judiciário". Judiciário que pode ser visto e observado, mas que não pode ser afetado pela plateia, que fica distante dele. Não à toa, o mesmo juiz que usou a metáfora da "vitrine" para me explicar o que era o Júri, interrompeu uma sessão de julgamento para repreender a plateia que estava mais agitada do que o costume. O homem, ao advertir os presentes do outro lado do vidro, disse-lhes através do microfone que "o julgamento é público, mas quem está assistindo tem que ter consciência de que não participa dele, o julgamento é público, mas quem assiste não participa”.

A mudança das instalações, com a saída do Júri do prédio que atualmente abriga o Museu do Judiciário e do 4o andar do Foro Central, simboliza também esse afastamento da sociedade. O Júri dos tempos de Evandro Lins e Silva funcionava no "Palácio da Justiça". Por isso, a expressão "Salão dos Passos Perdidos", intitula a obra sobre sua vida (LINS E SILVA, 1997). Ela foi cunhada por advogados criminalistas e juízes que atuavam no Júri e se refere ao espaço que antecede a entrada ao plenário desse edifício. O nome "passos perdidos" faz alusão ao trânsito dos advogados, réus e testemunhas, que caminham de modo ansioso, antes das sessões de julgamento.

Este prédio onde o júri anteriormente funcionada, está localizado próximo à rua, e podia ser acessado mais facilmente por aqueles que transitam pelo centro da cidade. A alternativa de concentrar todas as Varas no nono andar do edifício onde hoje funciona o Foro Central tem, portanto, duas consequências. Por um lado, aproximou os agentes, a quem foram reservados gabinetes vizinhos, localizados no mesmo espaço, lado a lado, no nono andar. Mas, por outro, acaba por afastar ainda mais o público. Isso porque, as novas instalações são muito mais difíceis de serem encontradas pelos usuários da justiça, pois estão dentro do Foro que, como descreverei a seguir, configura um emaranhado de corredores, escadas, elevadores e acessos. Assim, a transferência de prédio reflete as mudanças do Tribunal do Júri, cada vez mais vinculado ao poder judiciário e distante da sociedade, afastado dos cidadãos cariocas. Com isso, perde a dimensão de socialização da população sobre o funcionamento e administração da justiça, como identificado por Tocqueville (2005) no que se refere ao Júri americano. 


\section{CONCLUSÃO}

Para sustentar meu argumento, de que espaço das cortes judiciais, por ser um espaço social, reflete a forma como o se pensa a prestação jurisdicional, isto é, o "fazer justiça", me voltei para um tema pouco abordado sobre o fazer judicial, que é como o espaço físico do Júri, a partir da maneira como está organizado, fala sobre as ideologias subjacentes ao processo judicial e às dinâmicas de poder que dão conta dele (MULCAHY, 2007, p. 398). As mudanças que aconteceram no Júri da Comarca da Capital do Rio de Janeiro, tal como descritas ao longo desse artigo, foram pensadas pelo juiz titular da Vara em que fiz trabalho de campo. O magistrado, quando entrevistado por mim, disse que a reforma foi ótima porque "protegeu os jurados". Além dele, os demais agentes cujo trabalho acompanhei, não mencionavam esse impacto. Ao contrário, alguns deles, como a defensora Esmeralda, criticavam o afastamento da plateia, dizendo que deixaram de ter prazer em atuar naquele espaço, pois não podiam "sentir" a reação do público presente.

O afastamento do "povo", fala também sobre o afastamento das emoções, tal como Cardoso de Oliveira (2010, p. 461) aponta. Ao deslocar os envolvidos no caso e a plateia para um espaço mais distante e inserir um vidro blindado entre eles e os agentes do poder judiciário, inviabiliza-se a concretização da "dimensão do reconhecimento" que "remete a um direito de cidadania, associado a concepções de dignidade e de igualdade no mundo cívico, e não encontra respaldo específico em nossos tribunais" (CARDOSO DE OLIVEIRA, 2010, p. 461). De fato, o arranjo espacial do Tribunal do Júri da Comarca do Rio de Janeiro reforça o afastamento entre a sociedade e a justiça.

Procurei ressaltar, desse modo, como a mudança espacial refletiu no fazer judicial, na realização das audiências e explicitou suas características, traduzindo também visualmente a inquisitorialidade já fortemente demonstrada por Kant de Lima (2009) como traço marcante de nosso sistema de justiça criminal. O desenho do tribunal do júri reforçou o papel central do magistrado, demonstrando ser ele quem controla o ambiente e como sua figura pauta o andamento das sessões, tirando o foco dos jurados. O que surpreende é como isso contrasta com a concepção de julgamento do júri por parte da sociedade, isto é, pelo conselho de sentença, sendo estes últimos os responsáveis pela produção da decisão. Com a centralização do juiz, os jurados ganham o status de coadjuvantes, em um processo que deveriam ser centrais. 
Com isso quero dizer que a forma como o espaço está organizado ressalta, por contraste, tais concepções sobre os jurados, como de menor centralidade, quando comparados ao juiz. Traço este que reforça a dimensão inquisitorial de nossa justiça. Isso porque, como demonstrei, a partir da reforma, os jurados deixam de observar réus e testemunhas, ficando afastados da dimensão das emoções, ainda que como expressões obrigatórias dos sentimentos (MAUSS, 1979). Essas modificações espaciais, impactaram a maneira como o tribunal funciona, influenciando também o sentido da "participação popular", dando a ela as características próprias do que se pensa como tal, no contexto brasileiro, isto é, que é pouca, ou nenhuma atuação direta na justiça.

Ao longo da exposição, espero ter sido capaz de demonstrar a importância do que é dito no tribunal, não apenas de modo oral, mas de outras de diversas formas, isto é, por meio das demais dimensões simbólicas, tal como a organização espacial, a disposição dos móveis, os lugares que cada parte ocupa no contexto e como tais aspectos também falam e demonstram concepções de justiça. A existência de um vidro, ademais, remete à ideia de uma vitrine, assim como a presença de um telão, remete ao que pode ser visto, mas do que não de faz parte, pois está ali para exibição. Essa disposição espacial traduz um judiciário que pode ser visto, mas nem sempre pode ser acessado, à semelhança do que Kant de Lima (2009) fala sobre a apropriação dos conflitos que, transformados em lide processual, como categoria nativa, deixam de ter relevância e passam a ser decididos pelo judiciário, sem que aquilo que é importante para as partes, tenha sentido. Eis porque dizer que o Tribunal do Júri no brasil é "democrático" não faz sentido, exceto se pensarmos no significado que atribuímos ao termo que, cá entre nós, está mais para hierárquico e tutelar.

\section{REFERÊNCIAS BIBLIOGRÁFICAS:}

BONFIM, Edilson Mougenot. No tribunal do Júri: a arte e o ofício da Tribunais. São Paulo: Saraiva, 2000.

CARDOSO DE OLIVEIRA, Luis Roberto. A Dimensão Simbólica dos Direitos e a Análise de Conflitos. Revista de Antropologia, São Paulo, USP, v. 53, n. 2, 2010.

DAMO, Arlei Sander. Do dom à profissão: Uma etnografia do futebol de espetáculo a partir da formação de jogadores no Brasil e na França. 2005. 435 f. Tese (Doutorado em Antropologia). Programa de Pós-Graduação em Antropologia Social da Universidade Federal do Rio Grande do Sul. Porto Alegre, 2005. 
DUMONT, Louis. Homo Hierarquicus: o sistema de castas e suas implicações. $2^{\text {a }}$ ed. São Paulo: EDUSP, 1997 [1992].

DURKHEIM, Emile; MAUSS, Marcel. "Algumas formas primitivas de classificação". In: MAUSS, Marcel. Ensaios de Sociologia. $2^{a}$ ed. São Paulo: Perspectiva, 2009.

EILBAUM, Lucia . "O bairro fala": conflitos, moralidades e justiça no conurbano bonaerense. São Paulo: Editora Hucitec, 2012.

FERREIRA, Marco Aurélio Gonçalves. A presunção de Inocência e a Construção da Verdade. Rio de Janeiro: Lumen Juris, 2013.

HOLSTON, James. The modernist city: An anthropological critique of Brasília. Chicago: University of Chicago Press, 1989.

KANT DE LIMA, Roberto. Ensaios de Antropologia e de Direito: acesso à justiça e processos institucionais de administração de conflitos e produção de verdade em uma perspectiva comparada. Rio de Janeiro: Lumen Juris, 2009.

Sensibilidades jurídicas, saber e poder: bases culturais de alguns aspectos do direito brasileiro em uma perspectiva comparada. Anuário Antropológico, v. 2, p. 25-51, 2010.

LINS E SILVA, Evandro et al. O salão dos passos perdidos: depoimento ao CPDOC. Rio de Janeiro: FGV Editora, 1997.

MAUSS, M. A expressão obrigatória dos sentimentos. In: OLIVEIRA, Roberto Cardoso de. (org). Mauss: antropologia. (Coleção grandes cientistas sociais). São Paulo: Ática, 1979. p. 147 $-153$.

MULCAHY, Linda. Architects of justice: The politics of courtroom design. Social \& Legal Studies, v. 16, n. 3, p. 383-403, 2007.

NUÑEZ, Izabel Saenger. Aqui nós somos uma família: brigas e acordos no Tribunal do Júri. Rio de Janeiro: Autografia, 2021.

SCHRITZMEYER, Ana Lúcia Pastore. Julgamentos pelo Tribunal do Júri: Um Ritual Teatralizado e Lúdico. Boletim IBCCrim, São Paulo, ano 9, n. 109, p. 14-15, dez. 2001

TAVARES, Mirian. O Processo do Rei: a história no palco do cinema. ARS (São Paulo), v. 9, n. 17, p. 116-129, 2011.

VESENTINI, José William. A capital da geopolítica. São Paulo: Editora Ática, 1986. 